\title{
The role of maternal serum catestatin in the evaluation of preeclampsia and fetal cardiac functions
}

\section{Preeklampsi ve fetal kardiyak fonksiyonlarun değerlendirilmesinde maternal serum catestatinin rolü}

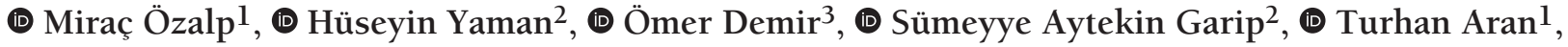 \\ (1) Mehmet Armağan Osmanağaoğlu1 \\ ${ }^{1}$ Karadeniz Technical University Faculty of Medicine, Department of Perinatology, Trabzon, Turkey \\ ${ }^{2}$ Karadeniz Technical University Faculty of Medicine, Department of Medical Biochemistry, Trabzon, Turkey \\ 3 Karadeniz Technical University Faculty of Medicine, Department of Gynecology and Obstetrics, Trabzon, Turkey
}

\begin{abstract}
Objective: To compare the maternal serum catestatin (CST) levels in pregnant women with preeclampsia (PE) and with normal blood pressure and evaluate the relationship between the maternal serum CST levels and fetal cardiac functions

Materials and Methods: This cross-sectional study was conducted on 27 women with early-onset PE (EOPE), 28 women with late-onset PE (LOPE), and 28 healthy pregnant women. Maternal serum CST levels were measured using the enzyme-linked immunosorbent assay kits. Fetal cardiac functions were evaluated using the cardiac Doppler.

Results: Maternal serum CST levels were lower in the EOPE group; however, no statistically significant difference was found between the groups. Compared with the other two groups, a statistically significant difference was found in the fetal E/A ratio and myocardial performance index (MPI) values of the EOPE group ( $\mathrm{p}=0.013, \mathrm{p}=0.002, \mathrm{p}=0.005, \mathrm{p}<0.001$, respectively). The fetal E/A ratio was positively correlated with the maternal serum CST levels in both the PE and control groups $(\mathrm{p}<0.001, \mathrm{p}<0.001)$. The fetal isovolumetric relaxation time and MPI values were negatively correlated with maternal serum CST levels in both the PE and control groups ( $\mathrm{p}<0.001, \mathrm{p}=0.001, \mathrm{p}<0.001$, and $\mathrm{p}=0.002$, respectively).

Conclusion: Lower CST levels are associated with fetal cardiovascular dysfunction, thus CST can be a critical biochemical marker in fetal cardiac function evaluation.

Keywords: Catestatin, cardiac function, Doppler, myocardial performance index, preeclampsia

$\mathrm{O} z$

Amaç: Preeklamptik (PE) ve normotansif gebelerin maternal serum catestatin (CST) düzeylerini karşılaştırmak ve maternal serum CST düzeyleri ile fetal kardiyak fonksiyonlar arasındaki ilişkiyi değerlendirmek.

Gereç ve Yöntemler: Bu kesitsel çalışma, erken başlangıçlı preeklampsili (EOPE) 27 gebe, geç başlangıçlı preeklampsili (LOPE) 28 gebe ve sağlıklı 28 gebe üzerinde yürütülmüştür. Maternal serum CST seviyeleri, enzime bağlı immünosorbent assay testleri kullanılarak ölçüldü. Fetal kardiyak fonksiyonlar, kardiyak Doppler ile değerlendirildi.

Bulgular: EOPE grubunda maternal serum CST düzeyleri daha düşük olmasına rağmen gruplar arasında istatistiksel olarak anlamlı fark bulunmadı. EOPE grubu diğer iki grupla karşılaştırıldığında, fetal E/A oranı ve miyokard performans indeksi (MPİ) değerlerinde istatistiksel olarak anlamlı fark bulundu (sirasiyla, $\mathrm{p}=0,013, \mathrm{p}=0,002, \mathrm{p}=0,005, \mathrm{p}<0,001)$. Fetal $\mathrm{E} / \mathrm{A}$ oranı hem preeklampsi hem de kontrol grubunda maternal serum CST seviyeleri ile pozitif korelasyon gösterdi $(\mathrm{p}<0,001, \mathrm{p}<0,001)$. Hem preeklampsi hem de kontrol grubunda fetal IRT (izovolümetrik relaksasyon zamanı) ve MPI değerleri maternal serum CST düzeyleri ile negatif korelasyon gösterdi (sırasiyla, $\mathrm{p}<0,001, \mathrm{p}=0,001, \mathrm{p}<0,001, \mathrm{p}=0,002$ ).

Sonuç: Düşük CST seviyeleri, fetal kardiyovasküler disfonksiyon ile ilişkilidir ve CST, fetal kalp fonksiyonunun değerlendirilmesinde kritik bir biyokimyasal belirteç olabilir.

Anahtar Kelimeler: Catestatin, kardiyak fonksiyon, Doppler, miyokardiyal performans indeksi, preeklampsi
\end{abstract}

PRECIS: We aimed to compare maternal serum catestatin levels of preeclamptic and normotensive pregnant women and to evaluation the relationship between maternal serum catestatin levels and fetal cardiac functions.

Address for Correspondence/Yazışma Adresi: Miraç Özalp MD, Karadeniz Technical University Faculty of Medicine, Department of Perinatology, Trabzon, Turkey Phone: +90 5052234093 E-mail: ozalpmirac@gmail.com ORCID ID: orcid.org/0000-0002-2255-1642

Received/Geliş Tarihi: 08.08.2021 Accepted/Kabul Tarihi: 17.10.2021

${ }^{\circledR}$ Copyright 2021 by Turkish Society of Obstetrics and Gynecology

Turkish Journal of Obstetrics and Gynecology published by Galenos Publishing House. 


\section{Introduction}

Preeclampsia (PE) is a critical disease affecting multiple organ systems in a normotensive woman, which occurs after the $20^{\text {th }}$ week of pregnancy with hypertension and proteinuria or progresses to hypertension and end-organ damage without proteinuria ${ }^{(1)}$. Complicating $2 \%-8 \%$ of all pregnancies, this situation is one of the leading causes of maternal and neonatal morbidity and mortality ${ }^{(1,2)}$.

The underlying mechanism of PE remains unclear; however, placental incompatibility appears as the main problem due to insufficient trophoblastic invasion of spiral arterioles ${ }^{(3)}$. Placental hypoxia and ischemia that develop due to this situation cause fetal heart expansion and increased aortic wall thickness, whereas the increased placental vascular resistance may cause fetal cardiac function changes by increasing fetal cardiac afterload ${ }^{(4,5)}$.

The effective way to evaluate the global cardiac function in fetal life is using the Doppler-derived myocardial performance index (MPI), independent heart rate, and ventricular geometry ${ }^{(6)}$. This index, first proposed by Tei et al. ${ }^{(7)}$, evaluates the myocardial function as a whole by combining both systolic and diastolic cardiac performance.

Catestatin (CST) is a hydrophobic and cationic structured peptide of 21 amino acids stored and released together with catecholamines in the storage vesicles of adrenal chromaffin cells and adrenergic neurons. It is obtained by degrading chromogranin A ( CgA) with proteolytic enzymes, such as serine protease plasmin and cysteine protease cathepsin $\mathrm{L}^{(8,9)}$. CST modulates the sympathoadrenal system by inhibiting catecholamine release via the neuronal nicotinic acetylcholine (Ach) receptors ${ }^{(8)}$. CST, which stimulates histamine release from mast cells via heterodimeric $G$ proteins, causes vasodilation and decreased blood pressure ${ }^{(9)}$. Other vital functions of CST include regulating the inotropy, lusitropy, and coronary tonus by increasing nitric oxide synthase, limiting apoptosis, providing proangiogenesis, and ultimately having cardioprotective effects $^{(10,11)}$. A study found low plasma CST levels not only in patients with hypertension but also in their normotensive children $^{(12)}$.

Firstly, this study aimed to compare the serum CST levels of pregnant women with PE and those normotensive. Another aim is to evaluate the cardiac function in fetuses of women with PE and those normotensive and reveal the relationship between the maternal serum CST levels and the fetal cardiac function.

\section{Materials and Methods}

This cross-sectional study was conducted between November 2020 and May 2021 at the Karadeniz Technical University Faculty of Medicine Perinatology Clinic. The study was approved by the Faculty of Medicine Ethics Committee of our University and was conducted following the Declaration of
Helsinki (ethics committee no: 2020/283, date: 16.11.2020). Written informed consent was obtained from all-volunteer pregnant women who participated in the study.

\section{Study Design}

A total of 55 patients with PE who were admitted to our clinic during the study period were randomly and consecutively chosen, wherein 27 were in the early-onset PE group (EOPE) and 28 in the late-onset PE group (LOPE). The normotensive control group consisted of 28 consecutive cases admitted to our clinic at the same date range (November 2020-May 2021), and whose ages and gestational ages matched with the study group. $\mathrm{PE}$ was diagnosed with the presence of hypertension (systolic and/or diastolic blood pressure of 140 and/or $90 \mathrm{mmHg}$ in two measurements made at least $4 \mathrm{~h}$ apart $)$ and proteinuria $(\geq 300 \mathrm{mg}$ in a 24-h urinalysis or urine protein/creatinine ratio of $\geq 0.3$ ) that occurred after the $20^{\text {th }}$ week of pregnancy in a woman who was previously normotensive ${ }^{(1)}$. Cases with new-onset hypertension without proteinuria were included in the PE group if they had a headache that is unresponsive to medical treatment, visual impairment, pulmonary edema, platelet count of $<100 \times 10^{9} / \mathrm{L}$, and signs and symptoms of end-organ damage, such as elevated blood concentrations of liver transaminases to twice the normal concentration, and serum creatinine concentration above 1.1 $\mathrm{mg} / \mathrm{dL}$ or a doubling of the serum creatinine concentration in the absence of other renal diseases ${ }^{(1)}$. PE was divided into two groups according to the gestational age of patient diagnoses; $<34$ weeks as EOPE and $\geq 34$ weeks as LOPE ${ }^{(13)}$. The pregnant women in the normotensive control group consisted of singleton and term pregnancies with infants showing an appropriate development according to the gestational age. The exclusion criteria include chronic hypertension, pregestational diabetes, premature rupture of membranes, chorioamnionitis, multiple pregnancies, fetal anomalies, autoimmune diseases, and maternal chronic liver and kidney diseases. No patients were excluded after the study completion since inclusion and exclusion criteria were met. Pregnancy outcomes and maternal demographic characteristics were obtained from the participants' medical records by a single clinician blinded to the fetal cardiac evaluation. The gestational age was confirmed by the last menstrual period and sonographic measurement of the crown-rump length in the early pregnancy period.

\section{Maternal CST Serum Concentrations}

After 12 hours of fasting, $5 \mathrm{~mL}$ of venous blood samples were obtained from all participants and placed in vacuum tubes without anticoagulants. Blood samples of pregnant women with PE were taken at the first visit after diagnosis. These samples were then centrifuged at $1800 \mathrm{~g}$ for $10 \mathrm{~min}$. Serum samples were stored at $-80^{\circ} \mathrm{C}$ until measurements were made. Serum CST levels were measured using an enzyme-linked immunosorbent assay (ELISA) kit (Bioassay Technology Laboratory, Shanghai, China, catalog no. E4996Hu). The test sensitivity was $0.046 \mathrm{ng} /$ 
$\mathrm{mL}(0.1-40 \mathrm{ng} / \mathrm{mL})$. Absorbance in specimens was measured at a $450 \mathrm{~nm}$ wavelength on a VERSA microplate reader (Molecular Devices in California, USA). Results are presented in $\mathrm{ng} / \mathrm{mL}$. The intra-assay (CV) reliability of this ELISA method was $<8 \%$, and that of the inter-assay distribution was $<10 \%$.

\section{Doppler Velocimetry}

Ultrasonographic evaluation of all participants was performed by the only specialist (M.O.) experienced in the fetal heart using the Voluson E10 (General Electrics Healthcare, Zipf, Austria) ultrasound system. MPI measurements were performed from the fetal left ventricle using the technique specified by Hernandez-Andrade et al. ${ }^{(14)}$. After obtaining the four-chamber of the heart in the transverse section of the fetal thorax, the probe was angled toward the left ventricular outflow tract. The Doppler sample was set to $3 \mathrm{~mm}$ and was positioned to contain both the lateral wall of the ascending aorta and the inner leaflet of the mitral valve (MV) so that the mitral inlet and the aortic outlet were simultaneously captured. During the MPI waveform measurement, attention was paid to the absence of fetal breathing or movement. The insonation angle was set to $<15$ degrees, the Doppler scan speed at $5 \mathrm{~cm} / \mathrm{s}$, and the wall motion filter at $300 \mathrm{~Hz}$. Measurements of three-time intervals were used: İsovolumetric contraction time (ICT), the time between the MV closure and the aortic valve (AV) opening; isovolumetric relaxation time (IRT), the time between AV closure and MV opening; and ejection time, (ET), the time between the AV opening and closure. MPI value was calculated with the formula: (ICT + IRT)/ET ${ }^{(7)}$. The peak velocity of the E wave represents early diastole with the MV opening and the peak velocity of the A wave resulting from atrial contraction in late diastole was determined as positive flow, and then the E/A ratio was calculated (Figure 1). Uterine artery Doppler evaluation was made as specified in the International Society of Ultrasound in Obstetrics and Gynecology guideline ${ }^{(15)}$.

The intraobserver reproducibility was assessed by calculating the intraclass correlation coefficients (ICC). ICC was 0.86 (95\% confidence interval: 0.82-0.90) for interobserver agreement. Women in the reliability study were excluded from the control group of the study.

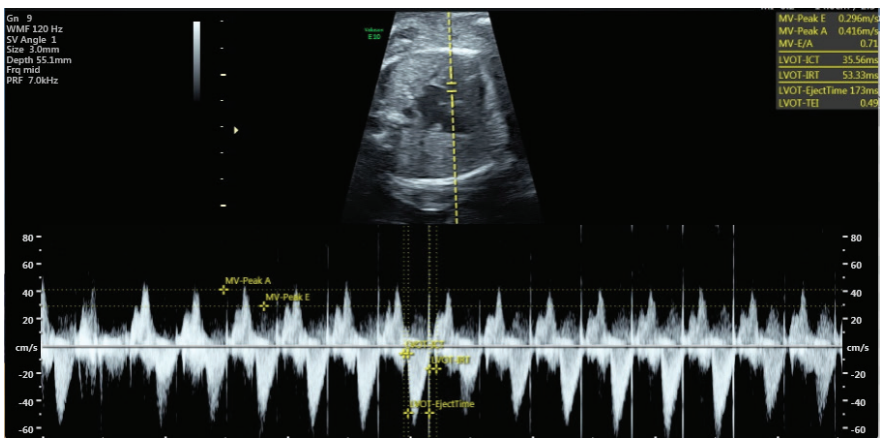

Figure 1. The myocardial performance index, E/A ratio, E and A waves peak velocity ratio at the mitral valve

\section{Statistical Analysis}

Statistical Package for the Social Sciences 21 program (IBM, $\mathrm{NY}$ ) designed for Windows was used for the statistical analysis. All continuous variables were defined as mean and standard deviation, whereas categorical variables were defined as a percentage of the total group. A p-value of $<0.05$ was statistically significant. The three groups were first compared using the Kruskal-Wallis test, then paired groups were compared using the Mann-Whitney $\mathrm{U}$ test and chi-square or Fischer test. The Mann-Whitney $U$ test was used to compare continuous variables in two groups. The chi-square or Fischer test was used to compare categorical variables. The relationship between the maternal serum CST levels and the fetal echocardiographic parameters was tested using the Pearson and Spearman correlation analyzes.

\section{Results}

Demographic and clinical characteristics and biochemical results are presented in Table 1. No significant difference was found between the groups in terms of age, gravida, parity, body mass index, aspartate aminotransferase, and platelet levels. When the control group was compared with the other two groups, a statistically significant difference was found between the groups in terms of systolic blood pressure, diastolic blood pressure, and uterine artery mean pulsatility index $(\mathrm{p}<0.001)$. The proteinuria value, blood sampling time, and ultrasound time in the EOPE group were statistically significantly different than the LOPE group ( $\mathrm{p}<0.001, \mathrm{p}=0.015, \mathrm{p}=0.015$, respectively). The maternal serum CST levels were low in the EOPE group; however, no statistically significant difference was found between the groups.

Perinatal results of cases are summarized in Table 2. The comparison of the EOPE group with the other two groups in terms of the gestational age at birth, fetal weight, $5^{\text {th }}$ minute Apgar score, and neonatal intensive care unit admission was statistically significant $(p<0.001)$. No significant difference was found in the cord $\mathrm{pH}$ values between the groups.

The echocardiography results, which evaluate the fetal cardiac functions, are shown in Table 3. The comparison of the EOPE group with the other two groups was statistically significant different in the fetal E/A ratio and MPI values ( $p=0.013$, $\mathrm{p}=0.002, \mathrm{p}=0.005, \mathrm{p}<0.001$, respectively). When the EOPE group and the control group were compared, a significant difference was found between the fetal $\mathrm{E}$ wave and IRT results ( $\mathrm{p}=0.046, \mathrm{p}=0.040$, respectively).

The correlation of the maternal serum CST levels with the fetal echocardiographic parameters for both the PE and control groups is presented in Table 4. The fetal E/A ratio was positively correlated with maternal serum CST levels in both the PE and control groups $(p<0.001, p<0.001$, respectively). The fetal IRT and MPI values were negatively correlated with the maternal serum CST levels in both the PE and control groups ( $p<0.001$, $\mathrm{p}=0.001, \mathrm{p}<0.001, \mathrm{p}=0.002$, respectively). 
Table 1. The comparison of the clinical and biochemical profiles of the study subjects

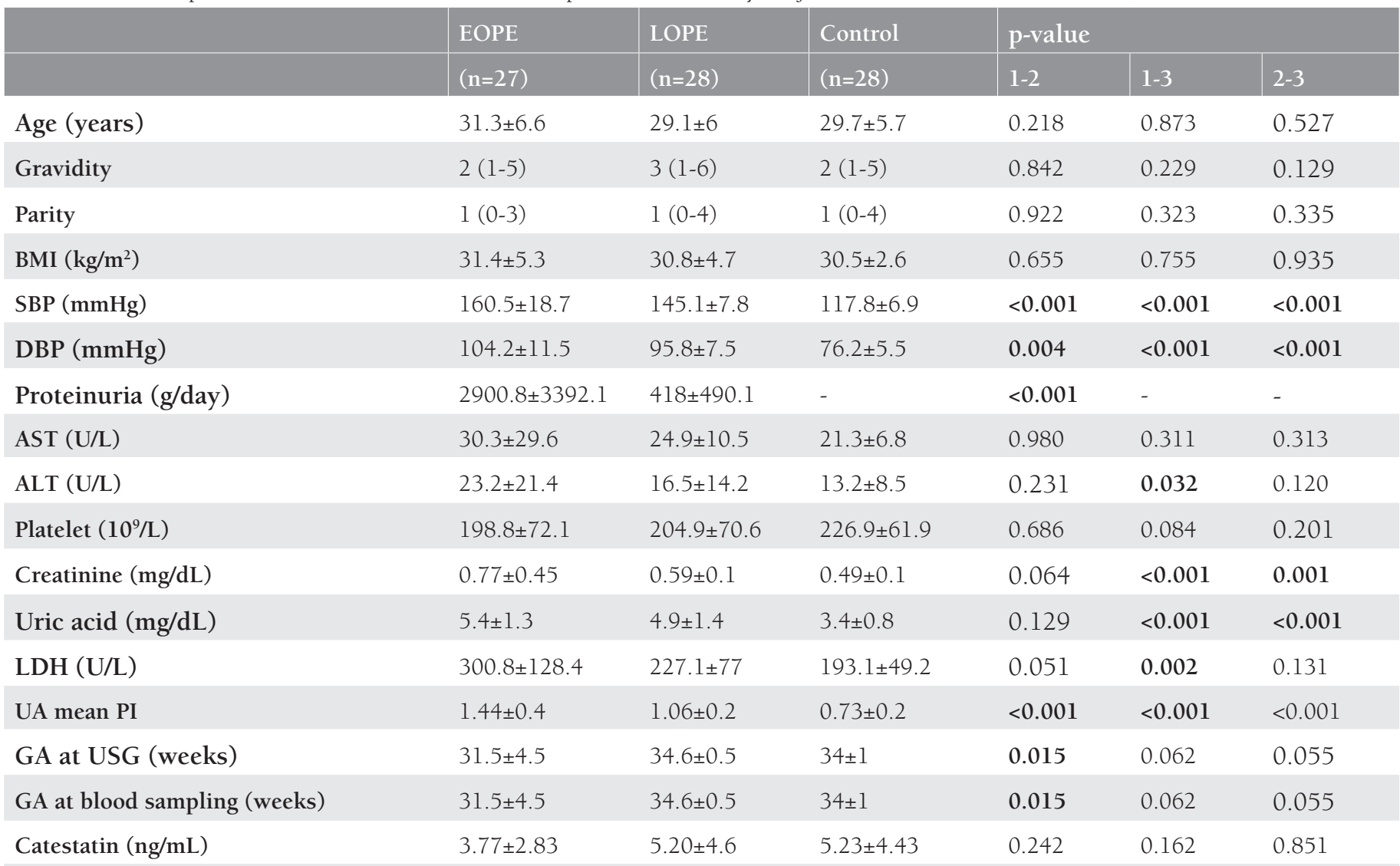

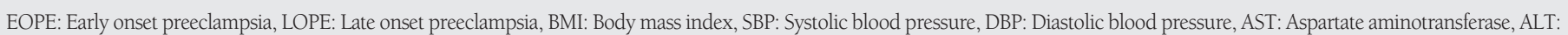
Alanine aminotransferase, LDH: Lactate dehydrogenase UA: Uterin artery, GA: Gestational age, USG: Ultrasonography

Table 2. Perinatal outcomes of EOPE, LOPE and control groups

\begin{tabular}{|c|c|c|c|c|c|c|}
\hline & $\begin{array}{l}\text { EOPE } \\
(n=27)\end{array}$ & $\frac{\text { LOPE }}{(n=28)}$ & $\begin{array}{l}\text { Control } \\
(n=28)\end{array}$ & \multicolumn{3}{|l|}{ p-value } \\
\hline GA at birth (weeks) & $31.5 \pm 4.5$ & $36.6 \pm 1$ & $38.8 \pm 1$ & $<0.001^{\mathrm{a}}$ & $<0.001^{\mathrm{a}}$ & $<0.001^{\mathrm{a}}$ \\
\hline Cesarean section rate (\%) & $24 / 27(88.9 \%)$ & $25 / 28(89.3 \%)$ & $17 / 28(60.7 \%)$ & $1^{\mathrm{c}}$ & $0.016^{b}$ & $0.014^{\mathrm{b}}$ \\
\hline Birth weight (g) & $1735 \pm 1061$ & $2952 \pm 658$ & $3334 \pm 409$ & $<0.001^{\mathrm{a}}$ & $<0.001^{\mathrm{a}}$ & $0.024^{\mathrm{a}}$ \\
\hline Apgar score $5^{\text {th }}$ min & $5.85 \pm 2.8$ & $8.3 \pm 1.1$ & $8.3 \pm 1.2$ & $<0.001^{\mathrm{a}}$ & $<0.001^{\mathrm{a}}$ & $1^{\mathrm{a}}$ \\
\hline NICU admission (\%) & $25 / 27(92.6 \%)$ & $12 / 28(42.9 \%)$ & $10 / 28(35.7 \%)$ & $<0.001^{\mathrm{b}}$ & $<0.001^{\mathrm{b}}$ & $0.584^{b}$ \\
\hline
\end{tabular}

${ }^{a}$ Mann-Whitney U test, ${ }^{b}$ Chi-square test, 'Fischer's exact test, GA: Gestational age, NICU: Neonatal intensive care unit, EOPE: Early onset preeclampsia, LOPE: Late onset preeclampsia

\section{Discussion}

This study evaluated the maternal serum CST levels and the fetal cardiac functions in pregnant women with PE and with normal blood pressure. Based on the known cardioprotective properties of the molecule, the relationship was examined between the maternal serum CST levels and the fetal cardiac functions. Only one recent study was reported in the literature evaluating the maternal serum CST levels in pregnant women with $\mathrm{PE}^{(16)}$. The study by Tüten et al. ${ }^{(16)}$ revealed that the maternal serum
CST levels were significantly higher in the PE group than that in the control group. Our study revealed low maternal serum CST levels in the EOPE group, but no statistically significant difference was observed between the groups. To the best of our knowledge, our study is the first study in the literature that evaluates the fetal cardiac functions in preeclamptic and control group pregnancies and examines their relationship with the maternal serum CST levels.

While the pathophysiology of PE is still controversial, partial or complete failure of placental implantation and trophoblastic 
Table 3. Fetal echocardiography results of EOPE, LOPE and control groups

\begin{tabular}{|c|c|c|c|c|c|c|}
\hline & EOPE & LOPE & Control & & p-value & \\
\hline Mitral E (cm/s) & $35.7 \pm 3.7$ & $37.6 \pm 3.6$ & $37.9 \pm 3.7$ & 0.770 & 0.046 & 0.934 \\
\hline Mitral A (cm/s) & $59.4 \pm 10.5$ & $56.7 \pm 6.5$ & $56.6 \pm 4.1$ & 0.203 & 0.215 & 0.532 \\
\hline Mitral E/A ratio & $0.61 \pm 0.06$ & $0.66 \pm 0.08$ & $0.67 \pm 0.07$ & 0.013 & 0.002 & 0.812 \\
\hline IRT (ms) & $48.9 \pm 4.7$ & $45.7 \pm 6.5$ & $44.9 \pm 7.3$ & 0.068 & 0.040 & 0.576 \\
\hline ET (ms) & $145 \pm 14.3$ & $146.4 \pm 14.5$ & $150.1 \pm 15.8$ & 0.846 & 0.270 & 0.275 \\
\hline MPI & $0.58 \pm 0.03$ & $0.54 \pm 0.05$ & $0.53 \pm 0.05$ & 0.005 & $<0.001$ & 0.197 \\
\hline
\end{tabular}

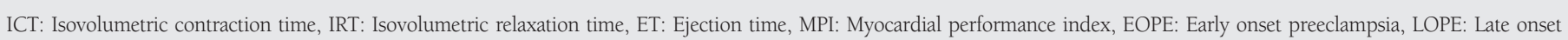
preeclampsia

Table 4. Correlation of maternal serum catestatin levels with fetal echocardiographic parameters in preeclampsia and control groups

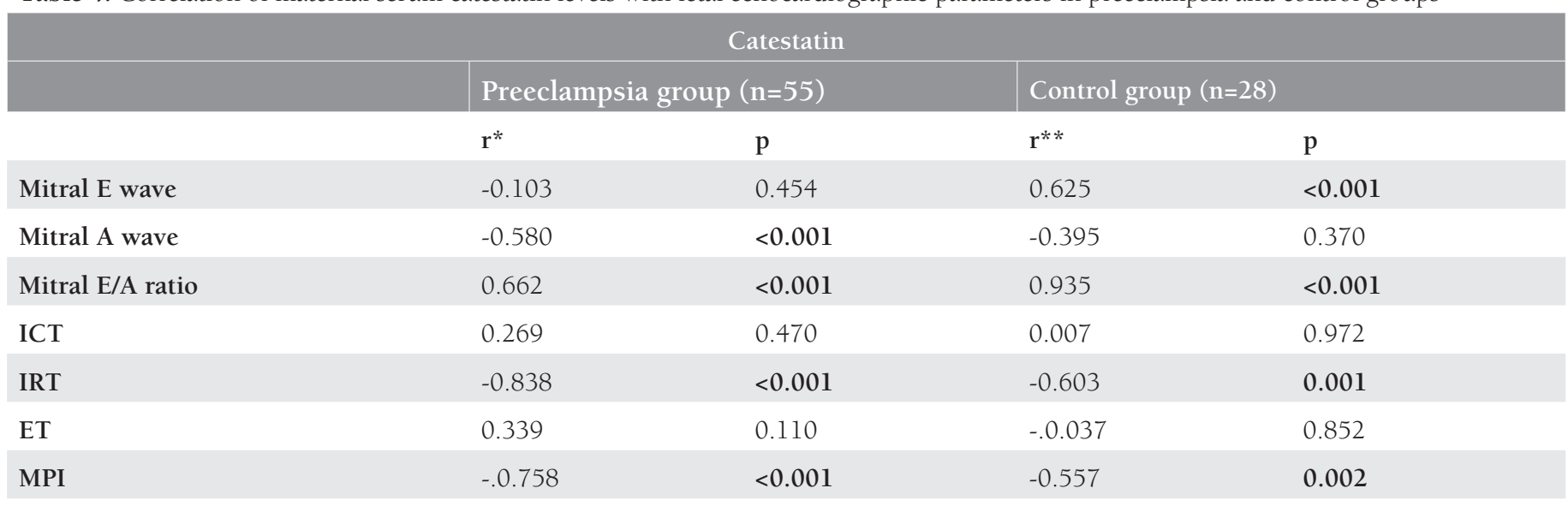

*Pearson correlation, **Spearman's rho ICT: Isovolumetric contraction time, IRT: Isovolumetric relaxation time, ET: Ejection time, MPI: Myocardial performance index

invasion are the main focus mechanisms ${ }^{(17,18)}$. Impaired Ach-mediated vasorelaxation due to developing endothelial dysfunction, decreased production of vasodilators such as nitric oxide and prostacyclin, increased production of vasoconstrictors such as endothelins and thromboxane, oxidative stress, and the changing rate of antiangiogenetic factors are other mechanisms that are thought to have a role in the disease. Another critical factor in the pathogenesis of PE is the increased sympathetic nervous system response ${ }^{(19)}$. Schobel et al. ${ }^{(20)}$ observed an increased sympathetic nerve activity in the muscles of women with PE compared to those who are normotensive. While antihypertensive responses to nonselective adrenergic receptor blockage are high in women with PE, baroreflex sensitivity has decreased ${ }^{(19,21)}$. Increased sympathetic activity in the early period was associated with placental hypoxia/reperfusion. Prohypertensive placental factors that develop due to hypoxia play a role in the development of PE by joining the maternal circulation $^{(22)}$. PE is divided into two groups according to the age of gestation upon diagnosis. While EOPE seems to be associated with poor placentation in the first trimester and represents a more severe clinical spectrum, the main problem in LOPE is the exaggerated maternal systemic inflammatory response ${ }^{(13)}$.

CST regulates the autonomic cardiovascular control at the central systemic level through the baroreceptor afferent fibers of the nucleus tractus solitarius ${ }^{(10)}$. CST, effective in the peripheral system by stimulating histamine release, inhibiting catecholamine release, and lowering blood pressure ${ }^{(11)}$. Fung et al. ${ }^{(9)}$ reported that decreased CST levels are associated with the risk of hypertension and the vasodilatory effect of local infusion of exogenous CST. Exogenous CST infusion provided normotension in CgA knock-out mice, representing a monogenic model of mouse hypertension ${ }^{(12)}$. In vivo CST also showed a supportive effect on angiogenesis/arteriogenesis and vasculogenesis in a unilateral mouse hindlimb ischemia model ${ }^{(23)}$. In our study, the maternal serum CST levels were lower in the EOPE group than that of the other two groups, but without a statistically significant difference. Tüten et al. ${ }^{(16)}$ found higher maternal serum CST levels in pregnant women with severe PE than those of the control group and stated that their results were not consistent with other studies conducted on patients with hypertension in the literature. Differences 
in the classification of PE (EOPE-LOPE/mild-severe) among studies caused changing results. In addition, Kiranmayi et al. ${ }^{(24)}$ revealed that the Gly364Ser allele, a common naturally occurring genetic variation of CST, is associated with high blood pressure levels. Genetic variants of CST that can affect autonomic activity can also change the risk of hypertension. Our study revealed that in fetuses in the EOPE group, MPI, which is a total indicator of cardiac function, significantly increased, whereas the E/A value, which was used to evaluate the diastolic cardiac function, significantly decreased. The high IRT value in the EOPE group is another parameter that indicates diastolic dysfunction in these fetuses. In a recently published study evaluating $>2000$ fetuses, the longitudinal reference ranges of fetal cardiac Doppler parameters were determined according to the weeks of gestation ${ }^{(25)}$. According to the study results, the mean values of fetal cardiac Doppler parameters and the $5^{\text {th }}$ and $95^{\text {th }}$ percentile values were similar in the mean ultrasound weeks of our EOPE and LOPE groups. Therefore, we think that the difference between the ultrasound times is not the main reason for the results in the EOPE and LOPE groups. We think that the mechanism that causes cardiac dysfunction in fetuses in the EOPE group is related to increased fetal cardiac afterload due to the increased placental vascular resistance. Compatible monitoring of fetal cardiac parameters in the control and LOPE groups may be associated with the milder placental involvement of the disease. Api et al. ${ }^{(26)}$ evaluated the cardiac functions of the PE group and the control group fetuses and could not find any differences between the MPI and E/A values of the groups. The study by Balli et al. ${ }^{(27)}$ evaluated the cases with mild PE and control groups and found that the IRT value was high in the PE group, but the MPI value was low, without any differences between the groups for the E/A value. In these studies, the case analyses in the PE group was not performed as early and late-onset subgroups, which may have a difference with the results of our study since the cause of cardiac dysfunction seems to be an increased cardiac afterload secondary to a more severe placental involvement in the EOPE group. Another recent study compared 60 fetuses with EOPE with 60 normotensive pregnant fetuses, which found a significantly lower E/A value in the EOPE group ${ }^{(28)}$. Considering the studies suggesting that babies of mothers with $\mathrm{PE}$ are more likely to develop heart diseases later in life, this may be related to changes in the cardiac function that begin in the in-utero period ${ }^{(17-19)}$.

Evidence accumulated in the literature points to the cardioprotective effects of CST. The sympathetic nervous system may contribute to the atherosclerosis process and the development of coronary artery disease ${ }^{(29)}$. Adrenergic overactivity may cause mechanical damage to the vascular wall due to increased blood pressure and increased flow rate $e^{(29,30)}$. CST demonstrates a protective effect on cardiac hypertrophy by reducing the pressure signal, and cardiac afterload also inhibits adrenergic stimulation in the heart and reduces myocardial ischemia/reperfusion injury ${ }^{(24,30)}$. At the organ level, CST has a negative inotropic effect in the myocardium and provides coronary dilatation through the $\beta 2$-adrenergic receptor-nitric oxide-cGMP signal and plays a role in the cardiovascular function regulation ${ }^{(10,29,30)}$. Our study evaluated the correlation of the maternal serum CST levels with the fetal cardiac function markers in separate groups and obtained moderate/strong correlation results, especially for MPI, E/A ratio, and IRT. Lower CST levels are associated with fetal cardiovascular dysfunction. We believe that the cardiac afterload reduction effect of CST against the increased fetal cardiac afterload, which results from the pathophysiology of $\mathrm{PE}$, is one of the crucial factors of these results.

\section{Study Limitations}

The primary strength of our study is its prospective design. Showing the effect of PE on fetal cardiac functions using the cardiac Doppler is important. This is the first study in the literature showing CST as an effective marker in evaluating fetal cardiac functions. However, our current study has some limitations. The relatively low number of cases in this crosssectional study may have prevented us from finding a significant difference for CST in cases with PE. In addition, the genetic variants of CST were not studied.

\section{Conclusion}

In summary, no significant difference was found between the maternal serum CST levels between the PE and the control groups in this study. EOPE can cause fetal cardiac function changes. Lower CST levels are associated with fetal cardiovascular dysfunction. CST may be a critical biochemical marker in the evaluation of fetal cardiac function.

\section{Ethics}

Ethics Committee Approval: The study was approved by the Faculty of Medicine Ethics Committee of our University and was conducted following the Declaration of Helsinki (ethics committee no: 2020/283, date: 16.11.2020).

Informed Consent: Written informed consent was obtained from all-volunteer pregnant women who participated in the study.

Peer-review: Externally peer-reviewed.

\section{Authorship Contributions}

Concept: M.Ö., H.Y., T.A., M.A.O., Design: M.Ö., H.Y., T.A., M.A.O., Data Collection or Processing: Ö.D., S.A.G., Analysis or Interpretation: M.Ö., Ö.D., S.A.G., Literature Search: Ö.D., S.A.G., Writing: M.Ö., H.Y., T.A., M.A.O.

Conflict of Interest: No conflict of interest was declared by the authors.

Financial Disclosure: The authors declared that this study received no financial support.

\section{References}

1. Gestational Hypertension and Preeclampsia: ACOG Practice Bulletin Summary, Number 222. Obstet Gynecol 2020;135:1492. 
2. Brown MA, Magee LA, Kenny LC, Karumanchi SA, McCarthy FP Saito S, et al. International Society for the Study of Hypertension in Pregnancy (ISSHP). Hypertensive Disorders of Pregnancy: ISSHP Classification, Diagnosis, and Management Recommendations for International Practice. Hypertension 2018;72:24-43.

3. Burton GJ, Redman CW, Roberts JM, Moffett A. Pre-eclampsia: pathophysiology and clinical implications. BMJ 2019;366:12381.

4. Ichizuka K, Matsuoka R, Hasegawa J, Shirato N, Jimbo M, Otsuki K, et al. The Tei index for evaluation of fetal myocardial performance in sick fetuses. Early Hum Dev 2005;81:273-9.

5. Narin N, Cetin N, Kiliç H, Başbuğ M, Narin F, Kafali M, et al. Diagnostic value of troponin $\mathrm{T}$ in neonates of mild pre-eclamptic mothers. Biol Neonate 1999;75:137-42.

6. Patey O, Carvalho JS, Thilaganathan B. Perinatal changes in fetal cardiac geometry and function in diabetic pregnancy at term. Ultrasound Obstet Gynecol 2019;54:634-42.

7. Tei C, Ling LH, Hodge DO, Bailey KR, Oh JK, Rodeheffer RJ, et al. New index of combined systolic and diastolic myocardial performance: a simple and reproducible measure of cardiac function--a study in normals and dilated cardiomyopathy. J Cardiol 1995;26:357-66.

8. Mahapatra NR. Catestatin is a novel endogenous peptide that regulates cardiac function and blood pressure. Cardiovasc Res 2008;80:330-8.

9. Fung MM, Salem RM, Mehtani P, Thomas B, Lu CF, Perez B, et al. Direct vasoactive effects of the chromogranin A (CHGA) peptide catestatin in humans in vivo. Clin Exp Hypertens 2010;32:278-87.

10. Mazza R, Tota B, Gattuso A. Cardio-vascular activity of catestatin: interlocking the puzzle pieces. Curr Med Chem 2015;22:292-304.

11. Mahata SK, Kiranmayi M, Mahapatra NR. Catestatin: A master regulator of cardiovascular functions. Curr Med Chem 2018;25:1352-74.

12. O'Connor DT, Kailasam MT, Kennedy BP, Ziegler MG, Yanaihara N, Parmer RJ. Early decline in the catecholamine release-inhibitory peptide catestatin in humans at genetic risk of hypertension. J Hypertens 2002;20:1335-45.

13. von Dadelszen P, Magee LA, Roberts JM. Subclassification of preeclampsia. Hypertens Pregnancy 2003;22:143-8.

14. Hernandez-Andrade E, López-Tenorio J, Figueroa-Diesel H, Sanin-Blair J, Carreras E, Cabero L, et al. A modified myocardial performance (Tei) index based on the use of valve clicks improves reproducibility of fetal left cardiac function assessment. Ultrasound Obstet Gynecol 2005;26:227-32

15. Bhide A, Acharya G, Baschat A, Bilardo CM, Brezinka C, Cafici D, et al. ISUOG Practice Guidelines (updated): use of Doppler velocimetry in obstetrics. Ultrasound Obstet Gynecol 2021;58:3319.

16. Tüten N, Güralp O, Gök K, Hamzaoglu K, Oner YO, Makul M, et al. Serum catestatin level is increased in women with preeclampsia. J Obstet Gynaecol 2021:1-6.
17. Redman CW, Staff AC. Preeclampsia, biomarkers, syncytiotrophoblast stress, and placental capacity. Am J Obstet Gynecol 2015;213:S9.e1-11.

18. Correa PJ, Palmeiro Y, Soto MJ, Ugarte C, Illanes SE. Etiopathogenesis, prediction, and prevention of preeclampsia. Hypertens Pregnancy 2016;35:280-94.

19. Spradley FT. Sympathetic nervous system control of vascular function and blood pressure during pregnancy and preeclampsia. J Hypertens 2019;37:476-87.

20. Schobel HP, Fischer T, Heuszer K, Geiger H, Schmieder RE. Preeclampsia -- a state of sympathetic overactivity. N Engl J Med 1996;335:1480-5.

21. Reyes LM, Usselman CW, Davenport MH, Steinback CD. Sympathetic nervous system regulation in human normotensive and hypertensive pregnancies. Hypertension 2018;71:793-803.

22. Karumanchi SA, Granger JP. Preeclampsia and pregnancy-related hypertensive disorders. Hypertension 2016;67:238-42.

23. Theurl M, Schgoer W, Albrecht K, Jeschke J, Egger M, Beer AG, et al. The neuropeptide catestatin acts as a novel angiogenic cytokine via a basic fibroblast growth factor-dependent mechanism. Circ Res 2010;107:1326-35.

24. Kiranmayi M, Chirasani VR, Allu PK, Subramanian L, Martelli EE, Sahu BS, et al. Catestatin Gly364Ser variant alters systemic blood pressure and the risk for hypertension in human populations via endothelial nitric oxide pathway. Hypertension 2016;68:334-47.

25. Sun L, WangJ, Su X, Chen X, Zhou Y, Zhang X, et al. Reference ranges of fetal heart function using a Modified Myocardial Performance Index: a prospective multicentre, cross-sectional study. BMJ Open 2021;11:e049640. doi: 10.1136/bmjopen-2021-049640.

26. Api O, Emeksiz MB, Api M, Ugurel V, Unal O. Modified myocardial performance index for evaluation of fetal cardiac function in preeclampsia. Ultrasound Obstet Gynecol 2009;33:51-7.

27. Balli S, Kibar AE, Ece I, Oflaz MB, Yilmaz O. Assessment of fetal cardiac function in mild preeclampsia. Pediatr Cardiol 2013;34:1674-9.

28. Bhorat IE, Bagratee JS, Reddy T. Assessment of fetal myocardial performance in severe early onset pre-eclampsia (EO-PET) with and without intrauterine growth restriction across deteriorating stages of placental vascular resistance and links to adverse outcomes. Eur J Obstet Gynecol Reprod Biol 2017;210:325-33.

29. Liu L, Ding W, Zhao F, Shi L, Pang Y, Tang C. Plasma levels and potential roles of catestatin in patients with coronary heart disease. Scand Cardiovasc J 2013;47:217-24.

30. Pasqua T, Angelone T, Spena A, Cerra MC. Biological roles of the eclectic chromogranin-a-derived peptide catestatin. Curr Med Chem 2017;24:3356-72. 